\author{
Odai Falah Mohammad AL-Ghaswyneh, \\ Assistant Professor, Marketing Department, \\ Northern Border University, \\ Arar, Saudi Arabia
}

\title{
PILLARS OF INTERNAL MARKETING AND THEIR IMPACT ON STAFF PERFORMANCE
}

This study focus on employees as an internal customer to the specifications that the working environment provides to them to achieve their tasks and increase staff's performance by examining their job satisfaction. The concept of internal marketing is to achieve the staff's satisfaction to satisfy customers' needs. Any organization that implements a retention policy for its high performing marketing professionals for its products, services and operations by providing them with awareness programs about its mission, objectives and customer requirements, will inevitably be able to improve its services provided by its staff. Analysis revealed that there is no statistically significant value below (0.05) for the main hypothesis of the study in terms of training, internal communications, promotion, incentive systems, and the dissatisfaction of the majority of employees about the internal marketing pillars applied by the university. This explains the low level of effectiveness of the internal marketing in terms of implementation and its impact on the professional performance of the majority of respondents from both genders. In comparing the statistical findings of the study sample, the majority of responses is that the university works on enhancing the work environment by using technology and direct connections with the staff, and by providing the required information to the staff to be able to perform their tasks without focusing on staff's satisfaction with training, incentive, and promotion in general. This requires conducting a study on how to develop the university's training, incentive and promotion systems by focusing on the characteristics of the current working environment and its relation with the prevailing work culture in the study community. Moreover, this requires highlighting the level of qualification and training of staff and its role in enhancing the professional performance, and the role of internal marketing as a novel concept in enhancing staff performance.

Keywords: internal marketing, promotion, incentives, training, internal administrative communications, university, employees, performance.

Introduction. As a discipline, marketing focuses on the communication between an organization and its external customers to satisfy their needs (Brooks, Lings, \& Botschen, 1999; Hsiao \& Ma, 2017; Vavra, 1992). This has been the case until a Japanese quality manager developed a new concept in the 1950s. He maintained that the activities performed by the staff are internal products purchased by external customers. As the competition increased among organizations, the concept of internal marketing was highlighted as one of the critical pillars of success for any organization providing services particularly educational services (Yildiz \& Kara, 2017). The philosophy of this concept is that the internal staff of an organization should be treated as internal customers within an internal market(Abbas \& Riaz, 2018). Supporting them by satisfying their needs and developing their skills is highly important, as it will improve the capabilities of the organization itself (Dahl \& Peltier, 2014). Like any other organization that works on developing its capabilities and customer satisfaction services, universities are educational institutions that render services and mutual benefits for all various segments of the community by treating them as external customers and its staff as internal customers. Therefore, adopting the internal marketing concept plays a critical role in developing the relationship between the university and its staff. Internal marketing considers all university staff as internal customers who should work on achieving the goals of the university. If the goals of universities stem from achieving the goals of external marketing, the roles attached to each staff should contribute to this goal through responding to the internal customers where each one of them is linked directly or indirectly to the end customers. This study is an attempt to identify the status of applying 
the concept of internal marketing to measure the performance of the NBU internal staff, the degree of applicability from the staff's perspective and to identify the problems and obstacles that could limit the application of this concept. Moreover, the study provides several recommendations on how to enforce this concept based on the study findings.

Theoretical Framework. The concept of internal marketing is to achieve the staff's satisfaction to satisfy customers' needs (Kotler, Keller, \& Lu, 2009). Any organization that implements a retention policy for its highly performing marketing professionals for its products, services and operations by providing them with awareness programs about its mission, objectives and customer requirements, will inevitably be able to improve its services provided by its staff according to Akroush, Abu-ElSamen, Samawi, and Odetallah (2013). This concept has been defined by Grönroos (1981) as an internal marketing targeting employees within the organization and as one of the necessary requirements for its success as well as Zaman, Javaid, Arshad, and Bibi (2012). As defined by Marshall, Baker, and Finn (1998); Internal marketing is the method by which professional employees within the business organization are treated as internal customers based on a set of procedures and steps implemented by the higher management such as attraction, recruitment, training, development, incentives, motivating, creativity and the provision of all necessary requirements for an effective job to achieve the objectives of all parties dealing with the organization. Aryee, Walumbwa, Seidu, and Otaye (2016); Kotler (2015) defined internal marketing as recruiting, training, and motivating human resources who are professionally capable of providing services to customers. The incentive system is an integral part of the concept of internal marketing. It includes ways and means of raising the morale of the outstanding or highly performing staff member to boost their loyalty to the organization itself as well as to enhance their aptitude to self-development, self-confidence, and efficiency to diligently continue performing higher. This could bring to the employee more satisfaction with the organization they work in as presented in a study by Rony and Suki (2017). Furthermore, this constitutes an optimum way to motivate the working team to compete towards more productivity and render services within the organization and to external customers to the highest standards. Moreover, the incentive system is a crucial component of the organization's policies as well as Tsai (2014). Another integral part of the internal marketing philosophy is training being one of the administrative activities that aims at increasing the productivity of employees and providing them with specialized professional knowledge that could support them in performing the roles and duties attached to their positions within the organization itself as mentioned by Boukis, Kaminakis, Siampos, and Kostopoulos (2015). Training also plays a vital role in honing the skills of the staff by bridging their weaknesses and gaps. Training is a systematic process that aims at changing the behaviour, knowledge, and motivation of the staff to enhance the degree of synchronization and synergy between the employees' characteristics and abilities with the work requirements (Ismail \& Sheriff, 2017). The training process differs from the promotion system in terms of purpose and content based on several factors. Training focuses on measuring the staff's capabilities and achievements and shortening the work cycle within an organization (Ahmed \& Rafiq, 2003). On the other hand, the promotion system focuses on assigning duties and functions higher than the functions and duties attached to a staff's current position within the administrative hierarchy of the organization by increasing employees' responsibilities, duties, and organizational status while raising employee's pay and other privileges (Andrews \& Shimp, 2017). Staff members are connected with their working group and their managers through an administrative communication network that is associated with other social and behavioural aspects. Such a communication network is of high importance as it provides the staff member with critical information and data to enable him/her to carry out his or her duties directly. It is a unique case of all the diverse human communication cycle within the organizational structure of an organization. It is a means of influencing the behaviour of staff and guiding them towards achieving the organization's goals and objectives (Shiu \& Yu, 2010). Almajali, Albashabsha, and Almajali (2016)conducted on the dimensions of internal marketing and its impact on achieving the staff's satisfaction and increasing their performance 
in the commercial banking sector. The study revealed a statistically significant impact of the internal marketing dimensions on job satisfaction and performance. On the other hand, the findings of another study Boukis et al. (2015) revealed a positive correlation between internal marketing with customer outcomes. Abbas and Riaz (2018)found out that upon implementing an internal marketing policy, banks could increase the employees' motivation and their job stability and in turn could lead to delivering highquality services that satisfy customers when banks apply internal marketing. Tsai (2014) indicated that there is a positive correlation between applying the concept of internal marketing and a positive customer service at hospitals and achieving the organizational commitment. Akroush et al. (2013)revealed that the internal marketing consists of six dimensions that highly affect the quality of service. Imam, Abbasi, Muneer, and Qadri (2013)conducted a study on the effect of performing internal marketing activities on the quality of the educational service offered by state and private universities, and the relationship between the quality of service and external customers' satisfaction. One of the study findings is that there is a statistical significance of the internal marketing activities on the quality of service provided to customers. Moreover, the study revealed that there is a statistical relationship between the quality of service and the satisfaction of the external customer indicates that the internal marketing programs have a significant impact on the staff's commitment to their organization and its profitability (Ismail \& Sheriff, 2017). Another study conducted by Abidin, Roslin, and Kamaluddin (2018)stresses the importance of adopting the concept of internal marketing as an introduction to human resources management, and as a key input to the education process. Moreover, the study addresses the associated effect on the quality of the educational outcomes and the student selection process in specific universities. Al-Najjar and Kalaf (2012) indicate that the quality of banking services provided by banks is adequate and that there is a positive correlation with a statistical significance between internal marketing and the quality of banking services. The study recommends that bank management should seek to achieve high levels of job satisfaction and to adopt the concept of internal marketing upon developing its customer satisfaction strategies that aim at addressing the requirements and needs of its customers. In his study, Shiu and Yu (2010) stress the importance of introducing the concept of internal marketing to the staff as the study reveals a correlation between internal marketing, organizational culture, and jobs incorporates. In summary, based on this argument, the measuring tools implemented to evaluate job satisfaction in an organization differ based on the type of the organization itself and its service processes within the internal marketing philosophy (George, 1990; Vavra, 1992). Moreover, its observed that shared factors are effecting on employees performance from human resources perspectives as well as Dahl and Peltier (2014); Yao, Chen, and Cai (2013); Kashive and Khanna (2017); Lussier and Hendon (2018).

Methodology. This study follows the descriptive analysis methodology. A tailored data collection tool has been designed to ensure compatibility with the study community.

Study Sample. The study sample consists of the KSA Northern Border University staff (NBU) (faculty members and admin staff). The total number of NBU staff is 2000 female and male employees with various job grades and professional experience. The study was conducted during the academic year 2016/2017.

Study Instrument. The study instrument has been designed after analyzing several relevant studies of Huang and Rundle-Thiele (2014); Hwang and Der-Jang (2005). Several sections of the study paragraphs were edited to ensure compatibility with the NBU community and HR system. Reliability Coefficient and Internal Consistency tests have been conducted as follows:

1. The survey was reviewed by a number of specialists in the field of evaluating the professional performance, human resources, and marketing. Following the review process, several changes have been made to the content of each section of the internal marketing pillars.

2. The reliability Alpha Cronbach Test has been applied and the result was $(0.968 \%)$. This result supports the evaluation process of the sub-hypotheses derived from the main hypothesis.

Hypothesis. The study outcome is a proposed hypothesis to be tested during the research as follows: 
There is a positive correlation between the pillars of internal marketing and the performance of the NBU staff in terms of (incentives, training courses, administrative communication system, and the promotion system) attributed to variables like: (gender, years of experience and scope of work) at ( $\alpha \leq 0.05)$.

The major hypothesis has four minor hypotheses which are examining each terms means, standard deviation and reliability coefficient. The rest of the detailed tests had been discussed within the grow-up study design.

Statistical Analysis. Multiple statistical procedures had been used in this study such as means, standard deviations, frequencies, percentages, Pearson's correlation as a bivariate effect size statistic, the independent group's t-test and One-way ANOVA, and Cranach's alpha test of reliability was used to test the internal consistency. The internal marketing in a university as concept was computed by summing the items which measured the employees perceptions toward communication, the promotion system, the incentive, and training concepts and dividing the result by four yielding an average internal marketing concept, however, we adjusted this factor using factor based weight obtained from the structural equation higher order model after confirming it using the AMOS program. The Relative Importance Index (RII) was computed for all the questionnaire items and domain perceptions to help identify top and bottom-ranked employees attitudes, opinions, and importance among these employees on the key indicators that measured their perceptions on internal marketing and its sub-domains. The (RII) computation method as devised by Holt (2014) was followed.

Reliability Analysis: The Cronbach's alpha test of internal consistency was used to assess the reliability of the 23-Likert-based items which measured the employees internal marketing concepts, the test suggested that the 23 items were internally consistent and measured what they were supposed to measure reliably, Cronbach's alpha=0.97, $N=142$. See table 1 of the Reliability test.

Table 1 - Reliability test

\begin{tabular}{|c|c|}
\hline Cronbach's Alpha & N of Items \\
\hline 0.968 & 23 \\
\hline
\end{tabular}

One hundred and forty-two university members (Academic and Managers) responded to the survey, out of which the majority $(n=100,70.4 \%)$ were male employees, and the rest were females. See table 2.

Table 2 - Respondents characteristics. $\mathrm{N}=142$.

\begin{tabular}{|c|c|c|}
\hline Variables & Frequency & Percentaqe \\
\hline \multicolumn{3}{|l|}{ Sex } \\
\hline Female & 42 & 29.6 \\
\hline Male & 100 & 70.4 \\
\hline \multicolumn{3}{|l|}{ Experience Years } \\
\hline$<5$ years & 40 & 28.2 \\
\hline 5-10 Years & 61 & 43 \\
\hline$>10$ years & 41 & 28.9 \\
\hline \multicolumn{3}{|l|}{ Role } \\
\hline Management Member & 88 & 62 \\
\hline Academic Member & 54 & 38 \\
\hline
\end{tabular}

The Relative Importance and the means and the standard deviations of the employees' responses to the indicators of the incentive system and training programs are displayed in table 3. 
Table 3 - The descriptive statistics and Relative Importance of the employee's responses to indicators of Incentive and Training systems. $\mathrm{N}=142$.

\begin{tabular}{|l|c|c|c|}
\hline \multicolumn{1}{|c|}{ Paragraph } & Mean (SD) & RII (\%) & Rank \\
\hline The Incentive System & & & \\
\hline $\begin{array}{l}\text { The University offers moral incentives as an appreciation of distinctive } \\
\text { employees' efforts upon their performance }\end{array}$ & $2.53(1.4)$ & 50.6 & $\mathbf{3}$ \\
\hline The incentive system offered at the university fits with the work I do & $2.56(1.3)$ & 51.1 & $\mathbf{2}$ \\
\hline $\begin{array}{l}\text { The University's incentive system is characterized by justice and } \\
\text { transparency }\end{array}$ & $2.44(1.3)$ & 48.7 & $\mathbf{4}$ \\
\hline Rewards system encourages teamwork & $2.82(1.4)$ & 56.5 & $\mathbf{1}$ \\
\hline In general, I am satisfied with the incentive system & $2.37(1.3)$ & 47.3 & $\mathbf{5}$ \\
\hline Training Program & & & \\
\hline $\begin{array}{l}\text { The training programs available at the university are adequate and } \\
\text { appropriate to the nature of my work }\end{array}$ & $2.77(1.3)$ & 55.4 & $\mathbf{4}$ \\
\hline $\begin{array}{l}\text { The University concerns training employees to develop their skills in } \\
\text { dealing with customers }\end{array}$ & $2.73(1.3)$ & 54.6 & $\mathbf{6}$ \\
\hline $\begin{array}{l}\text { I feel that provided training covers a real lack of experience and assisting } \\
\text { additional skills in my self-development }\end{array}$ & $2.83(1.3)$ & 56.6 & $\mathbf{2}$ \\
\hline The University offers regular training programs & $2.82(1.4)$ & 56.3 & $\mathbf{3}$ \\
\hline Offered courses in university are proper to my working nature & $2.90(1.3)$ & 57.9 & $\mathbf{1}$ \\
\hline $\begin{array}{l}\text { University administration considers employees training as an investment in } \\
\text { the human resources }\end{array}$ & $2.77(1.3)$ & 55.4 & $\mathbf{5}$ \\
\hline
\end{tabular}

The ranked means and relative importance is shown in the last column, which simply shows the top rated and the bottom and top relatively perceived indicators of both the Incentive System and the Training program in the university. However, any relative importance below $60 \%$ is considered poor in general. Next top rated indicator of perceived reward system was the employees perceived, denoting that employees general were between uncertain to disagreeing in general to whether their incentive system fits well with their daily work, which highlights the overall low perceived match between the reward system and the real work in general, in spite of the second top rank this indicator was rewarded on average too. The last indicator of the perceived reward system, which took the third rank in fact, which ranked midway between top and bottom relatively important indicators of the reward system anyways. This indicator was poorly perceived by the employees in general as well which highlighting the general uncertainty to the disagreement of these employees on whether their university invested in their training to enhance its human resource size.

The Internal communication and Promotion systems were also analyzed in the same manner, the results are shown in table 4 . The top-rated relatively important indicator of internal communication, which is relatively somewhere between uncertain to an agreement to whether they could communicate with their managers on any topics. In addition, it highlights their general disagreement to the acquired statements, this denotes that these employees perceived some form of impedance in the flow of necessary information between their peers and the employee's generalized uncertainty to disagreement in general to whether their university system real effort to enhance communication between staff was tangible to their workplace. The rest of the indicators were ranked somewhere between these top and bottom two indicators, please note their ranks in table 4. Likewise, the employees perceived Promotion System indicators and their relative importance are displayed to the bottom of the table 4 denoting that these employees were close by being uncertain in general to whether equitable chance of promotion is given to all employees in general, The rest of the indicators of the promotion system mingled somewhere between these two top and bottom-ranked indicators of the promotion system performance, please see the table 4 . 
Table 4 - The descriptive statistics and Relative Importance of the employee's responses to indicators of Internal communication and Promotion. N= 142.

\begin{tabular}{|l|c|c|c|}
\hline & Mean (SD) & RII(\%) & Rank \\
\hline Internal communications & & & \\
\hline I communicate directly with my managers on any issue of my business & $3.7(1.1)$ & 73.8 & $\mathbf{1}$ \\
\hline $\begin{array}{l}\text { The university follows an open door policy in communicating with all its } \\
\text { employees }\end{array}$ & $2.95(1.4)$ & 59.2 & $\mathbf{4}$ \\
\hline $\begin{array}{l}\text { The university relies on a good communication system that offers all the } \\
\text { information I need quickly }\end{array}$ & $2.86(1.2)$ & 57.2 & $\mathbf{5}$ \\
\hline $\begin{array}{l}\text { I get the information I need from top management and colleagues to carry out } \\
\text { required tasks }\end{array}$ & $3.32(1.2)$ & 66.5 & $\mathbf{2}$ \\
\hline $\begin{array}{l}\text { The university relies on modern techniques in communication between staff } \\
\text { and management }\end{array}$ & $3.10(1.4)$ & 61.3 & $\mathbf{3}$ \\
\hline $\begin{array}{l}\text { Staff shares their views on management decisions regarding employees' } \\
\text { affairs }\end{array}$ & $2.36(1.2)$ & 47.2 & $\mathbf{7}$ \\
\hline $\begin{array}{l}\text { The University is keen to encourage the communications of its employees to } \\
\text { improve the working environment }\end{array}$ & $2.59(1.2)$ & 52.0 & $\mathbf{6}$ \\
\hline Promotion System & & & \\
\hline University promotion policy is clear and easy to apply & $2.44(1.3)$ & 48.9 & $\mathbf{4}$ \\
\hline $\begin{array}{l}\text { Equal opportunities are available for all employees to meet the promotion } \\
\text { requirements }\end{array}$ & $2.62(1.3)$ & 52.4 & $\mathbf{1}$ \\
\hline The University's promotion policy is fair and transparent & $2.45(1.3)$ & 49.0 & $\mathbf{3}$ \\
\hline $\begin{array}{l}\text { The university promotion system is a catalyst compared to its counterparts in } \\
\text { other universities }\end{array}$ & $2.27(1.3)$ & 45.5 & $\mathbf{5}$ \\
\hline $\begin{array}{l}\text { The university promotion system is subject to development and modernization } \\
\text { based on the work environment' requirements }\end{array}$ & $2.53(1.3)$ & 50.6 & $\mathbf{2}$ \\
\hline
\end{tabular}

All in all, the employees perceived internal marketing was rated with 2.7 Likert points out of 5 , denoting the employee's agreement level toward their university's marketing optimization was close by undecided and disagreeing in general. As well, their overall perceived training program was rated with 2.8 Likert points out of 5 , which is between disagreeing and undecided to the usefulness, relevance, abundance, and adequacy of the offered training by their university. In the same way, the internal communication system was rated with the collective mean agreement of 3 out of 5 , denoting employees were generally unsure about their university's internal communication effectiveness. Too, the employee's general perception of the justice, fairness, and adequacy of their university promotion system was rated with 2.5 points out of 5 , highlighting their overall disagreement to uncertainty in general. The incentive system was perceived with a mean agreement of 2.6 out of 5 as well, denoting that these employees were close by uncertain but some of them are disagreeing in general to the fairness, completeness, usefulness, and justice of the incentives system at their workplace.

Table 5-Descriptive statistics of the Overall domains of the study

\begin{tabular}{|l|c|c|}
\hline & Mean (SD) & Rank \\
\hline Training Programs & $2.8(1.2)$ & 2 \\
\hline Internal communications & $3.0(1)$ & 1 \\
\hline Promotion systems & $2.50(1.2)$ & 4 \\
\hline Incentives & $2.60(1.2)$ & 3 \\
\hline Overall Internal marketing (Likert points 1-5) & $2.70(1)$ & \\
\hline
\end{tabular}


To assess the employees' demographic and professional expertise levels on their general perceived internal marketing we employed the independent group's t-test and the One-way ANOVA. The t-test indicated that there was a statistically significant difference between academic and managerial employees, the academic members had significantly higher perceived Overall Internal marketing (mean $=3, S D=0.9$ ) than their peers who are working in the administrative body (mean $=2.6, S D=1.1), p=0.011$. There were no statistically significant differences between male and female staff on their respective mean perception of overall internal marketing neither was a statistically significant difference, as well, across the employee's experience levels, please note above mentioned table 6 .

Table 6 - The statistical difference in mean Overall Internal marketing perception across the employee's demographic characteristics. $\mathrm{N}=$

\begin{tabular}{|c|l|c|c|c|}
\hline \multicolumn{2}{|c|}{} & Mean(SD) & test statistic & p \\
\hline \multirow{2}{*}{ Sex } & Female & $2.90(1.1)$ & $\mathrm{t}(140)=1.4$ & 0.169 \\
\cline { 2 - 5 } & Male & $2.64(1)$ & & \\
\hline \multirow{3}{*}{ Experience Years } & $<5$ years & $2.80(1)$ & $\mathrm{f}(2,139)=1.2$ & 0.306 \\
\cline { 2 - 5 } & $5-10$ Years & $2.57(1)$ & & \\
\cline { 2 - 5 } & $>10$ years & $2.78(0.95)$ & & 0.011 \\
\hline \multirow{2}{*}{ Role } & Management Member & $2.6(1.1)$ & $\mathrm{t}(140)=2.60$ & \\
\cline { 2 - 5 } & Academic Member & $3(0.9)$ & & \\
\hline
\end{tabular}

As well, to understand the effect of employees demographics and experience levels on their perception of the University Training Programs, we explored them using the t-test and the One-way ANOVA tests. Again, the Academic staff perceived significantly higher on their university Training Programs (mean = $3.1, \mathrm{SD}=1$ ) than the administrative staff (mean= 2.6, $S D=1.2$ ) denoting that the academic personnel perceived greater usefulness, abundance, relevance and adequacy of their university offered training than their peers in the administrative roles.

Likewise, Female staff perceived significantly higher usefulness and relevance of their university training (mean= 3.1, SD=1.2) than their male colleagues (mean= 2.7, $S D=1.2$ ), $p=0.053$. as shown in table 7 , there were no statistically significant differences between the employee's experience years on their perception of the training system.

Table 7 - The statistical difference between mean Overall University Training program perception across the employee's demographic characteristics. $\mathrm{N}=142$

\begin{tabular}{|c|c|c|c|}
\hline & Mean(SD) & test statistic & $p$ \\
\hline \multicolumn{4}{|l|}{ Sex } \\
\hline Female & $3.10(1.2)$ & $t(140)=1.95$ & 0.053 \\
\hline Male & $2.70(1.2)$ & & \\
\hline \multicolumn{4}{|l|}{ Experience Years } \\
\hline$<5$ years & $3.0(1.2)$ & $f(2,139)=0.97$ & 0.379 \\
\hline 5-10 Years & $2.67(1.2)$ & 1.20895 & \\
\hline$>10$ years & $2.80(1.2)$ & 1.15561 & \\
\hline \multicolumn{4}{|l|}{ Role } \\
\hline Management Member & $2.60(1.2)$ & & \\
\hline Academic Member & $3.1(1)$ & $t(140)=2.75$ & 0.007 \\
\hline
\end{tabular}

In the way, the employees perceived Internal Communication was assessed across the employee's gender, experience and role as shown in table 8. The academic staff perceived significantly greater internal communication than their management staff colleagues, (Academic: mean $=3.34, S D=0.82 \mathrm{Vs}$. 
Management: mean= $2.76, S D=1$ ), according to the independent samples t-test, $p=0.001$, this highlights the fact that academic staff perceived significantly greater openness, ease, speed, eloquence, facilitated communication between them and their peers compared to the administrative staff members. The two employee genders and their experience years did not differ statistically in their overall perceived internal communication

Table 8 - The statistical difference in mean Overall University Internal communication perception across the employee's demographic characteristics. $\mathrm{N}=142$.

\begin{tabular}{|c|c|c|c|}
\hline & Mean(SD) & test statistic & $p$ \\
\hline \multicolumn{4}{|l|}{ Sex } \\
\hline Female & $3(1)$ & $t(140)=0.432$ & 0.666 \\
\hline Male & $2.96(1)$ & & \\
\hline \multicolumn{4}{|l|}{ Experience Years } \\
\hline$<5$ years & $3.10(0.95)$ & $f(2,139)=0.68$ & 0.507 \\
\hline 5-10 Years & $2.90(1)$ & 1.02675 & \\
\hline$>10$ years & $3.0(1)$ & 0.95896 & \\
\hline \multicolumn{4}{|l|}{ Role } \\
\hline Management Member & $2.76(1)$ & $t(140)=3.53$ & 0.001 \\
\hline Academic Member & $3.34(0.82)$ & & \\
\hline
\end{tabular}

Although the Perceived promotion system did not differ significantly between male and female university staff and not even between their experience years levels, however the academic members perceived significantly greater promotion system ( mean=2.76, $S D=1.2$ ) than their administrative colleagues ( mean $=2.28, S D=1.2$ ), according to an independent groups t-test, $p=0.022$, denoting that these academic members tended to perceive generally greater on their university promotion system characteristics of morale, matches with work, justice, teamwork enhancement, and satisfaction than their male peers on average, as shown in table 9 .

Table 9 - The statistical difference in mean Overall University Promotion system across the employee's demographic characteristics. $\mathrm{N}=142$

\begin{tabular}{|c|c|c|c|c|}
\hline & & Mean(SD) & test statistic & $p$ \\
\hline \multirow{2}{*}{ Sex } & Female & $2.49(1.2)$ & $t(140)=0.144$ & 0.886 \\
\hline & Male & $2.45(1.2)$ & & \\
\hline \multirow{3}{*}{ Experience Years } & $<5$ years & $2.58(1.3)$ & $f(2,139)=0.29$ & 0.752 \\
\hline & 5-10 Years & $2.39(1.2)$ & & \\
\hline & $>10$ years & $2.46(1.1)$ & & \\
\hline \multirow{3}{*}{ Role } & Management Member & \multirow[t]{2}{*}{$2.28(1.2)$} & \multirow[t]{2}{*}{$t(140)=2.3$} & \\
\hline & \multirow{2}{*}{ Academic Member } & & & 0.022 \\
\hline & & $2.76(1.2)$ & & \\
\hline
\end{tabular}

As shown in table 10, the employees incentive system did not differ significantly between academic and administrative university staff and neither between their experience years levels, however the male staff members perceived significantly lower on their university incentive system ( mean=2.42, $S D=1.1$ ) than their female colleagues ( mean=2.83, $S D=1.2$ ), however according to an independent groups t-test, the difference was slightly significant, $p=0.059$, denoting that these female members tended to perceive general greater on their university promotion system clarity, equity, fairness, up-to-date and catalyzing attributes than their administrative peers on average. 
Table 10 - The statistical difference on mean Overall University Incentive system perception across the employee's demographic characteristics. $\mathrm{N}=142$

\begin{tabular}{|c|c|c|c|}
\hline & Mean(SD) & test statistic & $p$ \\
\hline \multicolumn{4}{|l|}{ Sex } \\
\hline Female & $2.83(1.2)$ & $t(140)=1.90$ & 0.059 \\
\hline Male & $2.42(1.1)$ & & \\
\hline \multicolumn{4}{|l|}{ Experience Years } \\
\hline$<5$ years & $2.74(1.2)$ & $f(2,139)=2.7$ & 0.071 \\
\hline 5-10 Years & $2.28(1.1)$ & 1.12746 & \\
\hline$>10$ years & $2.74(1.2)$ & 1.19117 & \\
\hline \multicolumn{4}{|l|}{ Role } \\
\hline Management Member & $2.51(1.2)$ & $t(140)=0.459$ & 0.647 \\
\hline Academic Member & $2.60(1.1)$ & & \\
\hline
\end{tabular}

Table 11 - Factor Score Weights (Group number 1 - conge)

\begin{tabular}{|c|c|c|c|c|c|}
\hline & Incent.sys & Promot & Internl.comm & Train.Programs & total \\
\hline Internal marketing & 0.221 & 0.197 & 0.25 & 0.331 & 0.999 \\
\hline weights & 0.221221221 & 0.197197197 & 0.25025025 & 0.331331331 & 1 \\
\hline
\end{tabular}

We used weights to examine internal marketing pillars as a group to implement correlation test later and it clear that training system is the most weighted pillar. See table 11 above.

Table 12 - Pearson`s Correlations between the internal marketing and its sub-domains. $\mathrm{N}=142$.

\begin{tabular}{|c|c|c|c|c|}
\hline & $\begin{array}{l}\text { Internal } \\
\text { marketing }\end{array}$ & $\begin{array}{l}\text { Training } \\
\text { Programs }\end{array}$ & Communications & $\begin{array}{l}\text { Promotion } \\
\text { systems }\end{array}$ \\
\hline Training Programs & $0.93^{* *}$ & & & \\
\hline Internal Communications & $0.86^{\text {th }}$ & $0.71^{* \star}$ & & \\
\hline Promotion System & $0.86^{\text {t* }}$ & $0.73^{* *}$ & $0.71^{* *}$ & \\
\hline Incentives System & $0.87^{\text {*t }}$ & $0.76^{* *}$ & $0.69^{* *}$ & $0.65^{* *}$ \\
\hline
\end{tabular}

The Pearson's correlation test was used to assess the association between the employees perceived internal marketing and its sub-domains. The correlation table 10 shows the Correlations between these concepts. In simple words, the training program was significantly but positively associated with the Internal marketing, $r=0.93, p<0.010$. Also, the employee's internal communication perception was significantly associated with their perceived Internal marketing, $r=0.86, p<0.010$. Likewise, the employee's promotion system was also positively and significantly associated with their perceived Internal marketing perception, $r=0.86, p<0.010$. In the same as the employee's perceived internal communication was significantly associated with higher perceptions of training programs on average, $r=0.71, p<0.010$. Too, greater employees perceived promotion systems was significantly associated with higher perceptions on Training programs, $r=0.73, p<0.001$. As well, greater employees perceived incentive system predicted higher perceived efficacy of training programs, $r=0.76, p<0.010$. Moreover, the employees perceived promotion and communication systems were also positively and significantly associated, as employees perceived promotion tended to rise, their perceived internal communication effectiveness tended to rise significantly too, $r=0.71$. Not only that but also the employees perceived incentive system perceptions correlated significantly with their perceived effective communications, $r=0.69, p<0.010$. Lastly and not least, the employees perceived incentive system effectiveness was significantly associated with their perceived promotion system effectiveness, those who perceived higher effective incentive system, and equitable and 
just opportunity tended to significantly correlate with greater perception on the promotion system too, $\mathrm{r}=$ $0.65, p<0.010$.

Table 13 - Multivariate Linear regression explaining the combined and individual relationship between the employee's characteristics and their perceived internal marketing. $\mathrm{N}=142$

\begin{tabular}{|c|c|c|c|c|c|}
\hline & B & Std. Err. & Beta & Standardized Beta & $p$ \\
\hline (Constant) & 2.852 & .245 & & 11.636 & .000 \\
\hline Sex= Male & -.442 & .195 & -.201 & -2.270 & .025 \\
\hline experience.yrs Experience years & -.019 & .112 & -.014 & -.170 & .865 \\
\hline job.type.rol Job type= Academic member & .576 & .178 & .278 & 3.238 & .002 \\
\hline
\end{tabular}

The multivariate linear regression analysis was employed to assess the combined and individual relationships between the employee's gender, experience years and their job role with their perceived overall internal marketing concept. The model was statistically significant, $f(3,138)=4.1, p=0.007$, denoting that one, or more, of the tested variables, had a significant multivariate association with the employees perceived internal marketing , and that the three independent variables accounted for ( i.e., explained ) a total of $28.9 \%$ of the variations between employees on their perceived internal marketing concept. To explain, the model suggested that male employees percei

ved significantly lower perceived university marketing standard than their female peers, $p=0.025$ while considering the other predictors as constant. Likewise, the Academic members perceived significantly greater perception of internal marketing than their colleagues who are an administrative, $p=0.002$. The experience years did not converge significantly on the employee's perception of their internal marketing, denoting there was no statistically significant effect on the employee's experience years on their perceived internal marketing in general.

Discussion of Findings. Based on the statistical analysis, Alpha Cronbach Test revealed a high correlation in the responses of the study sample conducted to test the relationship between internal marketing and professional performance. It reached (10\%) of the (142) NBU study respondents. The high internal statistical correlation supports the correlation in the study respondents. This supports the correlation in analyzing the rest of the survey items, which have some consistency and variation.

The Incentive Section. The study analysis revealed that the majority of academic and administrative staff did not show a minimum sign of consent about their satisfaction with the NBU incentive system. The Mean Likert Scale score is (2.6 out of 5 ) although the percentage was lower than the neutral mean. This uncertainty could be due to a variation in the values of the responses particularly in the section that indicates how the incentive system supports the teamwork spirit, which reached an average of (2.82). Teamwork enhances a number of factors and variables that are not limited to those associated with the incentive system itself but those variables that have to do with the culture of society and the working environment that have a significant impact on promoting the collaboration among the staff and this result approved by another study held by Phillips and Hickman (2017). Moreover, the general dissatisfaction about the incentive system could also be critical being an indicator of the staff overall dissatisfaction as shown in the last paragraph of the same field which scored an average value of (2.37). This indicates that the average response reveals an unsatisfactory indication. This was proved following a statistical survey on the dissatisfaction of the majority of employees with the incentives offered within the work environment particularly the staff who perform service-related tasks and roles as evidenced in a study of (Dul \& Ceylan, 2014); Epstein and Buhovac (2014); (Liu, Liu, Ding, \& Lin, 2015). Furthermore, the impact of this issue on enhancing job performance has not shown a strong correlation with internal marketing in terms of variables like (gender, years of experience and type of job). Compared to the academic staff, the admin staff proved to be less satisfied with the incentive system.

Training. Like the previous pillar, the study sample indicates there is no confirmation on the staff's 
satisfaction with the university's training system. Their response indicated a variation in sections tackling the correlation between dissatisfaction and tendency to neutral response. The overall rate score was (2.8 out of 5). This can be attributed to several factors that could affect the identification of the respondents' professional satisfaction with the training system as in the section that tackles the NBU training programs that correspond to the conditions and type of work assigned to employees. This section scored (2.9) followed by a survey on the degree of commitment to the NBU training courses, which supported the neutrality of respondents. Their neutrality could be attributed to their uncertain knowledge of the type of training offered at NBU or whether there are already training courses which are contrary to the responses of the majority of those who are already enrolled in training programs. As indicated in the analysis of response data, the non-confirmation of the respondents' satisfaction about the NBU training programs could be attributed to either their lack of awareness about the training activities and events due to an inactive internal media. This is evidenced by the findings of a study carried out by (Memon, Salleh, \& Baharom, 2016); Shahzadi, Javed, Pirzada, Nasreen, and Khanam (2014). Alternatively, this could be attributed to the fact that the targeted training group did not get the required spare time to enrol in the training courses because of the nature of their jobs. Moreover, their neutral response could be attributed to the fact that the nature of jobs assigned to them requires a plethora of specialized courses as in the case of corporates with an absolute centralized management or a centralized decision-making process such as tailored hierarchical capitalist corporates. This is confirmed by Pageaux (2014); Kim, Sting, and Loch (2014); Van Solinge and Henkens (2014). Furthermore, the impact of this area on enhancing job performance has not revealed any scores that indicate a probability relation between it and internal marketing in terms of variables like: (gender, years of experience and type of job). Compared to the academic staff, the admin staff was less satisfied with the training system.

Internal and Administrative Communications. The evaluation of respondents in this section varies somewhat from the other previous sections in terms of the average response, which scored (3 out of 5 ) on the Likert Scale. The highest score recorded in the section addressing the communication of the employee with the direct manager in the work environment was $(3.7 \%)$ which is contrary to the average response about the employees' sharing of their opinions regarding the decision-making process with regard to their HR affairs. Accordingly, performing all the processes and procedures pertaining to evaluating the performance of the staff is a priority to managers, and is far more important than issues like recruitment, incentives, and training as previously explained. Several previous studies highlighted the importance of the work environment in achieving the satisfaction of external clients and in performing the roles attached to their jobs in most for-profit companies as reported by previous studies as well as Andrews and Shimp (2017); Mathe, Scott-Halsell, and Roseman (2016); Nica (2016). As for the impact of the communication system on job performance, the response of respondents was neutral because their response to emphasize their satisfaction or dissatisfaction is associated with a number of issues related to using technology in communications and the availability of information about performing job tasks. Most sections in this field were below the neutral level. This could be attributed to the staff's general dissatisfaction about the role of this section in enhancing their job performance. Moreover, the effect of this area on promoting job performance did not reveal any strong correlation between it and the internal marketing in terms of variables like: (gender, years of experience and type of job). Moreover, admin staff, compared to the academic staff, were less satisfied with the internal and administrative communication system.

Promotion Section. In analyzing the results of the responses of this section, it proved there is dissatisfaction with the promotion system in general. Responses recorded an average score of ( 2.5 out of 5 ) on the Likert Scale. Although the average response is low, respondents' refrain from confirming this score was evident in a limited number of sections. The results varied on average, where the highest section scored (2.62) as the highest score regarding the equal opportunities for promotion among staff from their 
point of view. However, in comparing the NBU promotion system with other effective systems in other universities, it has a lower average score of (2.27). This score supports the findings of the analysis regarding the staff's dissatisfaction with the promotion system in general based on the pillars of the internal marketing tested in the statistical survey. Dissatisfaction among staff about the promotion system could be attributed to several factors such as the lack of cooperation among employees and underestimating the work environment being a place to perform roles and tasks. This was confirmed by previous studies of Aryee et al. (2016); Chiniara and Bentein (2016).

The majority of employees in all government universities have shown dissatisfaction with the promotion system in general. This was confirmed by several previous studies conducted on government universities as similar results shown by Andrews and Shimp (2017); Vratskikh, Al-Lozi, and Maqableh (2016). This could be attributed to the tendency of several universities to replicate or mirror the same promotion systems among each other without considering the exclusive nature and distinctive characteristics of the work environment for each university in terms of the dominant culture of its community and work environment, the level of training and professional development programs, and the incentive systems. This was confirmed by previous studies as well as Zaman et al. (2012) Epstein and Buhovac (2014). However, the majority of universities showing a high level of professional satisfaction with their overall employment system show that they have distinct functional advantages, particularly in the area of training and incentive systems. This is confirmed by a number of studies of Abbas and Riaz (2018); Shahzadi et al. (2014). Moreover, the impact of this area in enhancing job performance has not given a strong correlation between it and the internal marketing in terms of variables like: (gender, years of experience and type of job) and administration staff were less satisfied with the promotion system compared to the academic staff.

Correlation Coefficients. The study indicates a high level of correlation among the survey items in the four areas. Spearman Correlation Coefficient Test indicates that the area of training ranked first in terms of how it relates to other areas within the internal marketing items $(0.93 \%)$, followed by internal communications, the incentive system and finally the promotion system. Professional development training has a high correlation with the incentive system being a motivation for the staff to commit to training courses because of the benefits in enhancing the professional experience and enabling employees to perform their tasks accurately, thoroughly and expeditiously. This is proved by several studies, including findings of Memon et al. (2016); Shahzadi et al. (2014). On the other hand, the second high correlation is between training and the promotion system since training is an important issue in furnishing job promotion requirements in certain professional areas particularly in entities with a large pool of employees which require an appraisal system for both male and female employees based on their qualifications or based on their years of experience or service in the entity itself. This has been confirmed by a study carried out by Lu, Lu, Gursoy, and Neale (2016). Moreover, another strong correlation unleashed between training and internal communication since training is important in boosting the social communication among employees especially among departments that do not have direct connections between them. Therefore, training provides a direct communication hub that could facilitate tasks and ensure an uninterrupted information sharing and work cycle. Although this correlation scored the lowest value, it reached $(0.71 \%)$. Accordingly, training is a priority in promoting the concept of internal marketing and increasing staff performance.

Conclusion. Analysis revealed that there is no statistically significant value below $(0.05)$ for the main hypothesis of the study in terms of training, internal communications, promotion, incentive systems, and the dissatisfaction of the majority of employees about the internal marketing pillars applied by the university. This explains the low level of effectiveness of the internal marketing in terms of implementation and its impact on the professional performance of the majority of respondents from both genders. In comparing the statistical findings of the study sample, the majority of responses is that the university works on enhancing the work environment by using technology and direct connections with the staff, and by providing the required information to the staff to be able to perform their tasks without focusing on staff's satisfaction with training, 
incentive, and promotion in general. This requires conducting a study on how to develop the university's training, incentive and promotion systems by focusing on the characteristics of the current working environment and its relation with the prevailing work culture in the study community. Moreover, this requires highlighting the level of qualification and training of staff and its role in enhancing the professional performance, and the role of internal marketing as a novel concept in enhancing staff performance.

Acknowledgements. The authors wish to acknowledge the approval and the support of this research study by the grant no: (BA-2017-1-7-F-6962), from the Deanship of Scientific Research in Northern Border University, Box: 1321, Arar, P.O. 91431 Saudi Arabia.

Abbas, R. A., \& Riaz, M. T. (2018). The effect of internal marketing dimensions on organizational commitment of employees: An Investigation among Private Banks in Faisalabad, Pakistan (A study based on different dimensions of internal marketing).

Abidin, H. A. Z., Roslin, R. M., \& Kamaluddin, N. (2018). Internal Marketing and Employees' Performance: Relating Marketing Strategies in Human Resource Efforts. Paper presented at the Proceedings of the 2nd Advances in Business Research International Conference.

Ahmed, P. K., \& Rafiq, M. (2003). Internal marketing issues and challenges. European Journal of marketing, 37(9), 1177-1186.

Akroush, M. N., Abu-ElSamen, A. A., Samawi, G. A., \& Odetallah, A. L. (2013). Internal marketing and service quality in restaurants. Marketing Intelligence \& Planning, 31(4), 304-336.

Al-Najjar, S. M., \& Kalaf, K. H. (2012). Designing a balanced scorecard to measure a bank's performance: A case study. International journal of business administration, 3(4), 44.

Almajali, M., M, Albashabsha, A., A, \& Almajali, H., M. (2016). Effect of the Internal Marketing Dimensions on the Employee's Job Satisfaction and Its Effect on Their Performance in the Working Commercial Banks in the Karak Governorate. Jordan Journal of Business Administration, 407(3971), 1-31.

Andrews, J. C., \& Shimp, T. A. (2017). Advertising, promotion, and other aspects of integrated marketing communications: Nelson Education.

Aryee, S., Walumbwa, F. O., Seidu, E. Y., \& Otaye, L. E. (2016). Developing and leveraging human capital resource to promote service quality: Testing a theory of performance. Journal of management, 42(2), 480-499.

Boukis, A., Kaminakis, K., Siampos, A., \& Kostopoulos, I. (2015). Linking internal marketing with customer outcomes. Marketing Intelligence \& Planning, 33(3), 394-413.

Brooks, R. F., Lings, I. N., \& Botschen, M. A. (1999). Internal marketing and customer driven wavefronts. Service Industries Journal, 19(4), 49-67.

Chiniara, M., \& Bentein, K. (2016). Linking servant leadership to individual performance: Differentiating the mediating role of autonomy, competence and relatedness need satisfaction. The Leadership Quarterly, 27(1), 124-141.

Dahl, A. J., \& Peltier, J. W. (2014). Internal marketing and employee satisfaction and loyalty: cross-cultural scale validation in the context of US and German nurses. Journal of Consumer Satisfaction, Dissatisfaction and Complaining Behavior, 27, 43.

Dul, J., \& Ceylan, C. (2014). The Impact of a creativity-supporting work environment on a firm's product innovation performance. Journal of Product Innovation Management, 31(6), 1254-1267.

Epstein, M. J., \& Buhovac, A. R. (2014). Making sustainability work: Best practices in managing and measuring corporate social, environmental, and economic impacts: Berrett-Koehler Publishers.

George, W. R. (1990). Internal marketing and organizational behaviour: A partnership in developing customer-conscious employees at every level. journal of Business Research, 20(1), 63-70.

Grönroos, C. (1981). Internal marketing-an integral part of marketing theory. Marketing of services, 236, 238.

Holt, G. D. (2014). Asking questions, analysing answers: relative importance revisited. Construction Innovation, 14(1), 2-16.

Hsiao, A., \& Ma, E. (2017). Internal marketing. Routledge Handbook of Hospitality Marketing.

Huang, Y.-T., \& Rundle-Thiele, S. (2014). The moderating effect of cultural congruence on the internal marketing practice and employee satisfaction relationship: An empirical examination of Australian and Taiwanese born tourism employees. Tourism Management, 42, 196-206.

Hwang, S., \& Der-Jang, C. (2005). Relationships among internal marketing, employee job satisfaction and international hotel performance: An empirical study. International Journal of Management, 22(2), 285.

Imam, A., Abbasi, A. S., Muneer, S., \& Qadri, M. M. (2013). Organizational culture and performance of higher educational institutions: The mediating role of individual readiness for change. European Journal of Business and Management, 5(20), 23-34.

Ismail, W., \& Sheriff, N. (2017). The effect of internal marketing on organizational commitment: an empirical study in banking sector in Yemen. Polish Journal of Management Studies, 15.

Kashive, N., \& Khanna, V. T. (2017). Building employee brand equity to influence organization attractiveness and firm performance. International Journal of Business and Management, 12(2), 207.

Kim, Y. H., Sting, F. J., \& Loch, C. H. (2014). Top-down, bottom-up, or both? Toward an integrative perspective on operations strategy formation. Journal of Operations Management, 32(7-8), 462-474.

Kotler, P. (2015). Framework for marketing management: Pearson Education India. 


\section{O. F. M. AL-Ghaswyneh. Pillars of Internal Marketing and their Impact on Staff Performance}

Kotler, P., Keller, K. L., \& Lu, T. (2009). Marketing management in China: Prentice Hall.

Liu, M.-L., Liu, N.-T., Ding, C. G., \& Lin, C.-P. (2015). Exploring team performance in high-tech industries: Future trends of building up teamwork. Technological Forecasting and Social Change, 91, 295-310.

Lu, L., Lu, A. C. C., Gursoy, D., \& Neale, N. R. (2016). Work engagement, job satisfaction, and turnover intentions: A comparison between supervisors and line-level employees. International Journal of Contemporary Hospitality Management, 28(4), 737-761.

Lussier, R. N., \& Hendon, J. R. (2018). Human resource management: Functions, applications, and skill development: Sage publications.

Marshall, G. W., Baker, J., \& Finn, D. W. (1998). Exploring internal customer service quality. Journal of Business \& Industrial Marketing, 13(4/5), 381-392.

Mathe, K., Scott-Halsell, S., \& Roseman, M. (2016). The role of customer orientation in the relationship between manager communications and customer satisfaction. Journal of Hospitality \& Tourism Research, 40(2), 198-209.

Memon, M. A., Salleh, R., \& Baharom, M. N. R. (2016). The link between training satisfaction, work engagement and turnover intention. European Journal of Training and Development, 40(6), 407-429.

Nica, E. (2016). The effect of perceived organizational support on organizational commitment and employee performance. Journal of Self-Governance and Management Economics, 4(4), 34-40.

Pageaux, B. (2014). The psychobiological model of endurance performance: an effort-based decision-making theory to explain self-paced endurance performance. Sports Medicine, 44(9), 1319.

Phillips, J. L., \& Hickman, L. D. (2017). INTEGRATED CARE AND MULTIDISCIPLINARY TEAMWORK. Contexts of Nursing: An Introduction, 219.

Rony, N. I., \& Suki, N. M. (2017). Modelling the Relationships between Internal Marketing Factors and Employee Job Satisfaction in Oil and Gas Industry. Asian Social Science, 13(3), 135.

Shahzadi, I., Javed, A., Pirzada, S. S., Nasreen, S., \& Khanam, F. (2014). Impact of employee motivation on employee performance. European Journal of Business and Management, 6(23), 159-166.

Shiu, Y.-M., \& Yu, T.-W. (2010). Internal marketing, organisational culture, job satisfaction, and organisational performance in non-life insurance. The Service Industries Journal, 30(6), 793-809.

Tsai, Y. (2014). Learning organizations, internal marketing, and organizational commitment in hospitals. BMC health services research, 14(1), 152.

Van Solinge, H., \& Henkens, K. (2014). Work-related factors as predictors in the retirement decision-making process of older workers in the Netherlands. Ageing \& Society, 34(9), 1551-1574.

Vavra, T. G. (1992). Aftermarketing: How to keep customers for life through relationship marketing: Irwin Professional Pub.

Vratskikh, I., Al-Lozi, M., \& Maqableh, M. (2016). The Impact of Emotional Intelligence on Job Performance via the Mediating Role of Job Satisfaction. International Journal of Business and Management, 11(2), 69.

Yao, Q., Chen, R., \& Cai, G. (2013). How internal marketing can cultivate psychological empowerment and enhance employee performance. Social Behavior and Personality: an international journal, 41(4), 529-537.

Yildiz, S. M., \& Kara, A. (2017). A unidimensional instrument for measuring internal marketing concept in the higher education sector: IM-11 scale. Quality Assurance in Education, 25(3).

Zaman, K., Javaid, N., Arshad, A., \& Bibi, S. (2012). Impact of internal marketing on market orientation and business performance. International Journal of Business and Social Science, 3(12).

Одія Фалах Мухаммед Аль-Гасвінех, асистент, Північно-прикордонний університет (Арар, Саудівська Аравія).

Основні компоненти внутрішнього маркетингу та ї вплив на ефективність роботи персоналу

Метою даного дослідження $є$ аналіз роботи працівників та факторів, що впливають на ефектииність виконання ними поставлених цілей та завдань. В рамках дослідження внутрішній маркетинг розелядається як метод просування цінностей та місії компанії з метою зміцнення системи взаємовідносин організації та персоналу. Автор систематизував наукові підходи до визначення сутності концепції внутрішнього маркетингу, визначив його місие в системі управління організацією. Автором запропоновано та перевірено гіпотезу про взаємозв'язок між підвищенням продуктивності праці персоналу та впровадженням інструментів внутрішнього маркетингу. Перевірка гіпотези здійснювалась на базі Північно-прикордонного навчального закладу KSE (Саудівська Аравія). Дослідження проводилось протягом 2016/2017 навального року серед 2000 працівників університету з урахуванням їх профресійного досвіду та посад. У роботі було використано економетричні методи аналізу ANOVA та AMOS. Результати аналізу показали, що впровадження внутрішнього маркетингу (навчання, тренінги, внутрішні комунікаиії, система стимулювання та ін.) має статистично значимий зв'язок з особистісним сприйняттям працівниками його результатів. Низький рівень ефеективності внутрішнього маркетингу спостерігався для більшості респондентів незалежно від гендерної ознаки. Отримані дані опитування показали, що керівництво університету зосереджує свою увагу на поліпшенні умов праці, впроваджуючи технології внутрішньої комунікації без урахуванням рівня задоволеності персоналу інструментами внутрішнього маркетингу. Автором визначено необхідність активізації творчого та інноваційного потенціалу працівників через підвищення ефеективності впровадження інструментів внутрішнього маркетингу з метою покращення внутрішньо-корпоративного клімату університету.

Ключові слова: внутрішній маркетинг, заохочення, стимули, навчання, внутрішня адміністративна комунікація, університет, співробітники, продуктивність. 